\title{
Article \\ Effect of Sake Lees on the Inhibition of Lipid Accumulation in Adipocytes
}

\author{
Yuki Motono ${ }^{1, *}$, Takeshi Imai ${ }^{2}$, Takashi Emi ${ }^{3}$, Takafumi Iguchi ${ }^{3}$ and Motoko Takaoka ${ }^{4}$ \\ 1 Department of Human Science, Graduate School, Kobe College, Hyogo 662-0825, Japan \\ 2 Hyogo Prefectural Institute of Technology, Hyogo 654-0037, Japan; imai@hyogo-kg.jp \\ 3 YAEGAKI Bio-Industry, Inc., Hyogo 679-4298, Japan; takashi.emi@yaegaki.com (T.E.); \\ takafumi.iguchi@yaegaki.com (T.I.) \\ 4 Department of Biosphere Sciences, Kobe College, Hyogo 662-0825, Japan; takaoka@mail.kobe-c.ac.jp \\ * Correspondence: gh1891ym@kc.kobe-c.ac.jp; Tel.: +81-798-51-8423
}

Citation: Motono, Y.; Imai, T.; Emi, T.; Iguchi, T.; Takaoka, M. Effect of Sake Lees on the Inhibition of Lipid Accumulation in Adipocytes. Fermentation 2021, 7, 145. https:// doi.org/10.3390/fermentation7030145

Academic Editor: Hiroshi Kitagaki

Received: 8 June 2021

Accepted: 3 August 2021

Published: 4 August 2021

Publisher's Note: MDPI stays neutral with regard to jurisdictional claims in published maps and institutional affiliations.

Copyright: (C) 2021 by the authors. Licensee MDPI, Basel, Switzerland. This article is an open access article distributed under the terms and conditions of the Creative Commons Attribution (CC BY) license (https:/ / creativecommons.org/licenses/by/ $4.0 /)$.

\begin{abstract}
Recent lifestyle changes, such as the Westernization of diets and the rise in the prevalence of obesity, with an associated increase in the number of patients with lifestyle-related diseases, have become a social issue. Fermented food has attracted attention as a solution to problems caused by obesity. Sake lees, a byproduct of sake brewing, represent one such food that is expected to have health benefits. In this study, we investigated the effects of sake lees components on preadipocytes (3T3-L1). We cultured preadipocytes in a medium with indigestible sake lees components (ISLCs) to investigate lipid accumulation, analyzed the glycerol 3-phosphate dehydrogenase (GPDH) and LPL activities of those cells, and performed a real-time PCR analysis of the IL6 expression in the cells. The results show that lipid accumulation and GPDH activity were significantly decreased in adipocytes treated with $1.0 \mathrm{mg} / \mathrm{mL}$ ISLCs compared to untreated cells. Furthermore, the expression of IL6 in adipocytes treated with $1.0 \mathrm{mg} / \mathrm{mL}$ ISLCs was significantly decreased and the lipase activity was significantly increased in adipocytes treated with ISLCs after differentiation. IL6 is known to have multiple functions in adipose tissue. In conclusion, ISLCs were associated with reduced lipid accumulation in adipocytes, with effects on IL6 expression and LPL activity observed throughout the differentiation period.
\end{abstract}

Keywords: sake lees; 3T3-L1 adipocyte; lipid accumulation; GPDH activity; real-time PCR; IL6; LPL activity

\section{Introduction}

In the 1980s, the mean life span of the Japanese general population became the world's longest [1]. While Japan is still known as a country with a healthy and long-living populace, the proportion of obese people has recently increased due to changes in lifestyle such as Westernized diets [2,3]. Japan's prevalence of obesity is now a social issue [4].

Obesity results from an accumulation of excess triglycerides stored in adipocyte cells due to energy intake exceeding energy expenditure. Adipocytes usually secrete hundreds of adipocytokines that have proinflammatory and anti-inflammatory properties. When adipocytes increase in size due to excessive energy intake, they produce more proinflammatory adipocytokines. Malignant adipocytokines are closely related to lifestylerelated diseases; therefore, adipocyte proliferation is linked to the occurrence of lifestylerelated diseases.

Interest has grown in the use of fermented foods as a technique to solve obesity-related health problems $[5,6]$. Sake lees, a byproduct of sake brewing, represent a fermented food with health benefits $[7,8]$. Sake lees consist of components of rice, yeast, and koji (a fungus used in the brewing process, the metabolites of which are highly nutritious and rich in amino acids, peptides, and dietary fiber). Animal studies have revealed that sake lees have functional properties, such as inhibiting cholesterol increase, lowering blood pressure, 
and inhibiting liver damage in mice. Moreover, clinical studies have reported improved environmental conditions in human intestines $[9,10]$. However, the mechanisms of action of sake lees and the roles of their specific components are unknown.

On the other hand, although IL6 is a pluripotent cytokine secreted by many different types of cells and tissues, overexpression by adipose tissue is a strong predictor of abnormalities in adipocytes and systemic metabolism [11,12]. In obese people, IL6 expression is increased in adipose tissue [13]. Therefore, we hypothesized that, by analyzing the expression of IL6 in adipocytes, we might be able to clarify the mechanism underlying the effect of sake lees on IL6 and their effect on lipolysis.

In this study, we investigated the effects of the indigestible components of sake lees on lipid accumulation in adipocytes. In order to investigate the mechanism underlying the inhibition of adipocyte fat accumulation, we analyzed the expression level of IL6 in cells cultured in a medium containing indigestible sake lees components.

\section{Materials and Methods}

\subsection{Materials}

Sake lees were refermented at $25^{\circ} \mathrm{C}$ for 3 days. The precipitate from the re-fermented mixture was collected by filtration and incubated at $60^{\circ} \mathrm{C}$ for $2 \mathrm{~h}$ to remove the fat. The residue was collected by filtration, lyophilized, and powderized to obtain ISLCs. The composition of ISLCs is shown in Table 1.

Table 1. Composition of ISLCs. The contents of the components in $100 \mathrm{~g}$ of ISLCs are shown.

\begin{tabular}{cc}
\hline Composition & Content $(\mathbf{g} / \mathbf{1 0 0} \mathbf{g})$ \\
\hline Protein & 57.4 \\
\hline Fat & 5.4 \\
\hline Carbohydrate & 29.6 \\
\hline Moisture & 6.5 \\
\hline Ash & 1.1 \\
\hline Dietary fiber & 25.7 \\
\hline
\end{tabular}

The ISLCs were diluted in distilled water at a ratio of $9 \mathrm{~mL}$ of water per $1 \mathrm{~g}$ of ISLCs and heated at $100{ }^{\circ} \mathrm{C}$ for $20 \mathrm{~min}$. The solution was then centrifuged, and the supernatant was used for the experiment.

\subsection{Cell Culture}

Mouse 3T3-L1 cells (Japanese Collection of Research Bioresources Cell Bank, Osaka, Japan) were grown in Dulbecco's modified Eagle's medium (DMEM) (with a high glucose content $(4500 \mathrm{mg} / \mathrm{L}), 1 \%$ antibiotics, and $10 \%$ fetal bovine serum (FBS)) at a temperature of $37{ }^{\circ} \mathrm{C}$ in $5 \% \mathrm{CO}_{2}$ until confluence was achieved. Cell differentiation was induced by placing the cells in DMEM supplemented with $0.5 \mathrm{mM}$ 3-isobutyl-1-methylxanthine (IBMX), $0.25 \mu \mathrm{M}$ dexamethasone (DEX), 10\% FBS, and $10 \mu \mathrm{g} / \mathrm{mL}$ insulin. Furthermore, $1.0 \mathrm{mg} / \mathrm{mL}$ ISLCs was added to the differentiation medium of the cells to create a group of treated cells, while the remainder of the cells acted as non-ISCLs-treated controls. The cells were incubated for $48 \mathrm{~h}$; the differentiation medium was replaced with DMEM containing $10 \% \mathrm{FBS}$ and $5 \mu \mathrm{g} / \mathrm{mL}$ of insulin, and this was changed every $48 \mathrm{~h}$ for 8 days.

\subsection{Oil Red O Stain}

Oil Red O staining was used to assess lipid accumulation in fully differentiated adipocyte cells collected 8 days after confluence. Adipocytes were fixed with $10 \%$ formalin for $1 \mathrm{~h}$, after which the fixing solution was removed. The cells were subsequently stained with filtered $0.3 \%$ Oil Red O solution in 60\% isopropanol for $1 \mathrm{~h}$ before the staining solution was removed by washing with water. Oil Red O was then eluted with isopropanol, 
and the cells were dried. Absorbance in the eluate was measured at $560 \mathrm{~nm}$ using a microplate reader.

\subsection{GPDH Activity}

GPDH activity was measured using a GPDH activity assay kit (TAKARA BIO INC., Shiga, Japan) in 3T3-L1 cells collected 4 and 8 days after differentiation was initiated. The cells were washed twice with PBS and scraped into the enzyme extract buffer provided with a GPDH activity assay kit. The collected cells were centrifuged at $10,000 \times \mathrm{g}$ for $5 \mathrm{~min}$ at $4{ }^{\circ} \mathrm{C}$ to remove the fat fraction, and the liquid component was used as the experimental sample. Following the removal of nicotinamide adenine di-nucleotide via an enzyme-catalyzed dihydroxyacetone phosphate reduction, the GPDH activity was spectrophotometrically determined at $340 \mathrm{~nm}$.

\subsection{LPL Activity Assay}

LPL is an enzyme that regulates the uptake of circulating triglycerides into adipocytes. LPL activity was measured using a lipase activity assay kit (Cayman Chemical, Ann Arbor, Michigan, USA) in 3T3-L1 cells collected 2, 4, and 8 days after cell differentiation. The activity was read as the cell fluorescence at $37^{\circ} \mathrm{C}$ every $30 \mathrm{~s}$ for $15 \mathrm{~min}$ using an excitation wavelength of $385 \mathrm{~nm}$ and an emission wavelength of $515 \mathrm{~nm}$. One unit of LPL activity was defined as the amount of enzyme that led to the formation of $1 \mathrm{nmol}$ of triglycerol per min.

\subsection{Real-Time PCR Analysis}

We used real-time PCR to analyze IL6 gene expression in adipocytes treated with sake lees. The mRNA was extracted from 3T3-L1 cells collected 2, 4, and 8 days after cell differentiation commenced, using a Nucleo Spin RNA ${ }^{\circledR}$ Kit (TAKARA BIO INC., Shiga, Japan). The recovered mRNA was used to synthesize first-strand cDNA using a PrimeScript RT reagent kit with IL6 primers (Cosmo Bio Co., Ltd., Tokyo, Japan). The primer sequences used for real-time PCR analysis are shown in Table 2. Adipocyte IL6 gene expression was analyzed using 39 cycles of real-time PCR at $95^{\circ} \mathrm{C}$ for $5 \mathrm{~s}$ and $60{ }^{\circ} \mathrm{C}$ for $30 \mathrm{~s}$. The change in expression was analyzed using the $\Delta \Delta \mathrm{Ct}$ method and normalized to an internal control of glyceraldehyde-3-phosphate dehydrogenase (GAPDH) mRNA.

Table 2. The primer sequences used for real-time PCR analysis.

\begin{tabular}{cc}
\hline & Primer Sequence \\
\hline IL6 & CCAACAGACCTGTCT[A]TACCACTTCACAAG \\
\hline GAPDH & GACAAAATGGTGAAG[G]TCGGTGTGAACGGA \\
\hline
\end{tabular}

\subsection{Statistical Analysis}

All data are expressed as the mean \pm standard deviation. Dunnett's method was used to assess the lipid accumulation rate and GPDH activity, whereas Student's t-test was used to describe the LPL activity and IL6 gene expression. Accordingly, $p$-values $<0.05$ and $<0.01$ were considered significant. Excel Tokei (Version 2.12: Social Survey Research Information Co., Ltd., Tokyo, Japan.) was used for data analysis.

\section{Results}

\subsection{Lipid Accumulation}

The lipid accumulation rate of each sample of indigestible ingredients was calculated using the fat content of cells in the no-addition group as a control. In the cells treated with $1.0 \mathrm{mg} / \mathrm{mL}$ ISLCs, the lipid accumulation was $80.9 \% \pm 6.1 \%$ of that in non-ISLC-treated cells (Figure 1). 
A)

Control

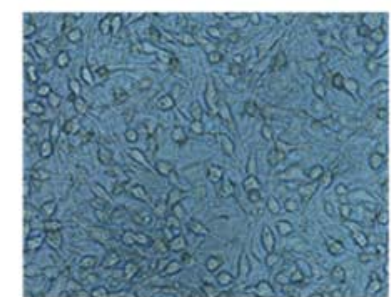

ISLCs

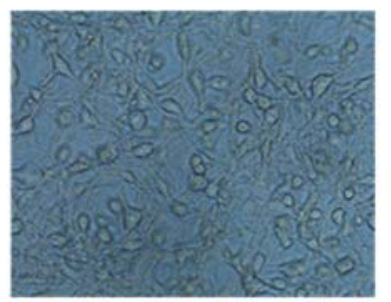

day 4
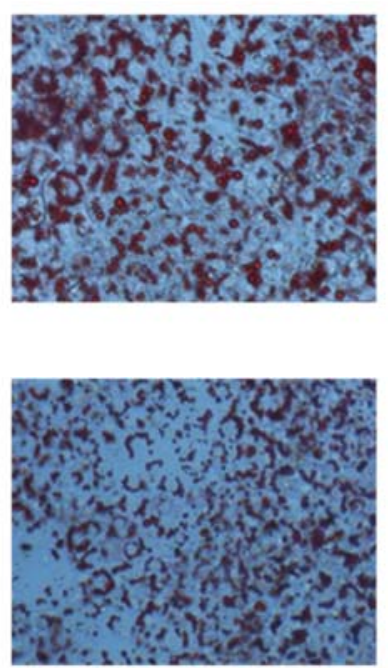

day 8
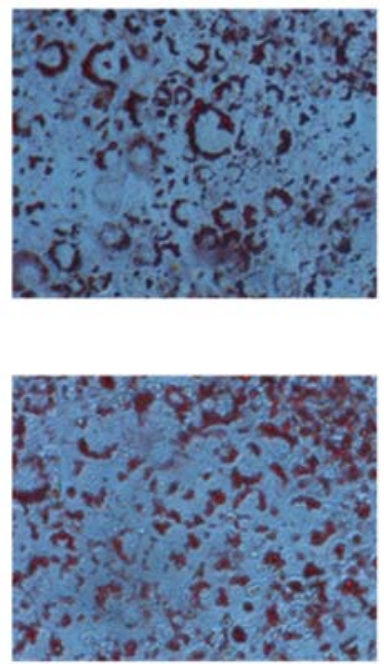

B)

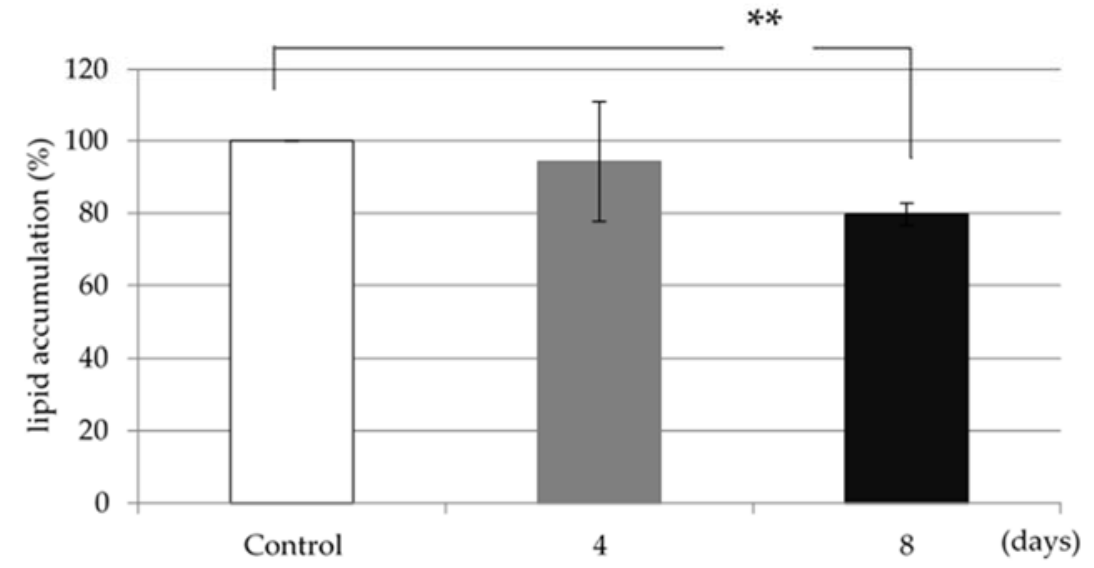

Figure 1. Effect of ISLCs on lipid accumulation in 3T3-L1 cells. (A) Lipid droplets of control cells and ISLC-treated cells after Oil Red O staining. (B) Comparison of lipid accumulation in 3T3-L1 cells. The cells were cultured in medium including $1.0 \mathrm{mg} / \mathrm{mL}$ ISLCs for 4 and 8 days after differentiation. The cells in the medium without ISLCs were used as a control. The ratio of lipid accumulation was expressed relative to untreated control cells $(100 \%)$. Values are expressed as the mean \pm SD; ** $p<0.01$, compared to control cells.

\subsection{GPDH Activity}

The GPDH activity 4 days after differentiation did not differ between the ISCL-treated and control cells; however, the GPDH activity was significantly decreased in the treated cells collected on day 8 (Figure 2).

\subsection{LPL Activity}

The LPL activity was increased in 3T3-L1 cells treated with $1.0 \mathrm{mg} / \mathrm{mL}$ ISLCs compared to control cells; this increase was statistically significant (Figure 3).

\subsection{Adipocyte IL6 Gene Expression}

Adipocyte IL6 gene expression was decreased in 3T3-L1 cells treated with $1.0 \mathrm{mg} / \mathrm{mL}$ ISLCs, collected on days 2, 4, and 8 after differentiation when compared to that in nonISLC-treated cells; this decrease was statistically significant (Figure 4). 


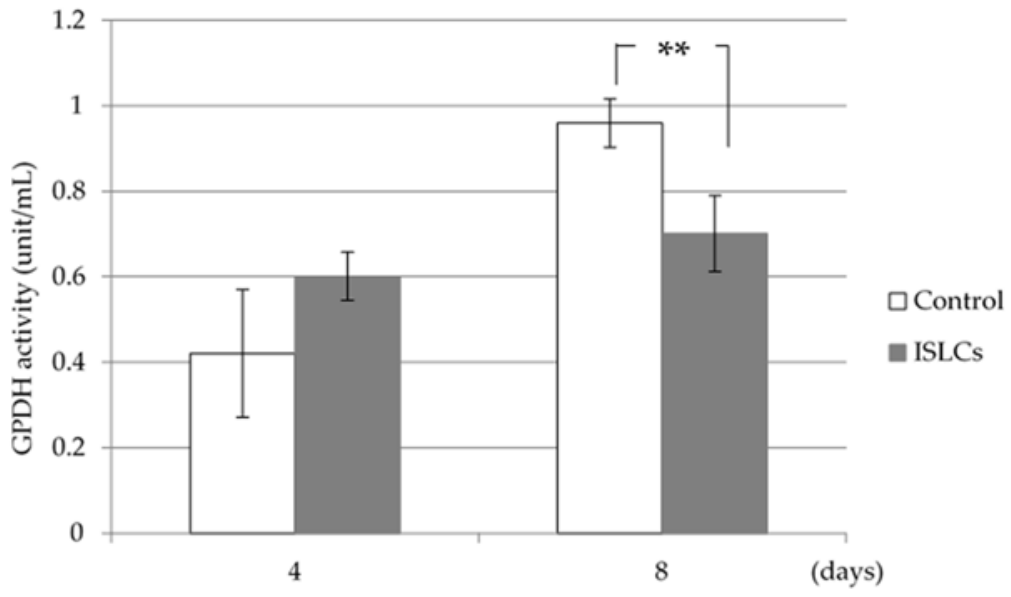

Figure 2. Effect of ISLCs on the GPDH activity of 3T3-L1 cells 4 and 8 days after differentiation. The cells were cultured for 4 and 8 days in medium containing $1.0 \mathrm{mg} / \mathrm{mL}$ ISLCs. The cells in the medium without ISLCs were used as a control. Values are expressed as the mean $\pm \mathrm{SD} ;{ }^{* *} p<0.01$, compared to control cells.

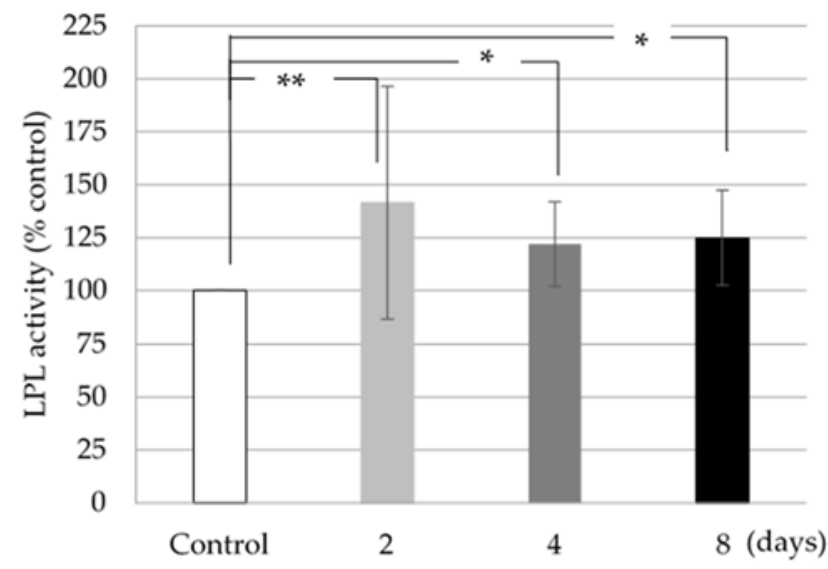

Figure 3. Effect of ISLCs on the lipoprotein lipase activity of 3T3-L1 cells 2, 4, and 8 days after differentiation. The cells were cultured in medium containing $1.0 \mathrm{mg} / \mathrm{mL}$ ISLCs. The cells in the medium without ISLCs were used as a control. Values are expressed as the mean $\pm \mathrm{SD} ;{ }^{*} p<0.05$, ** $p<0.01$, compared to control cells.

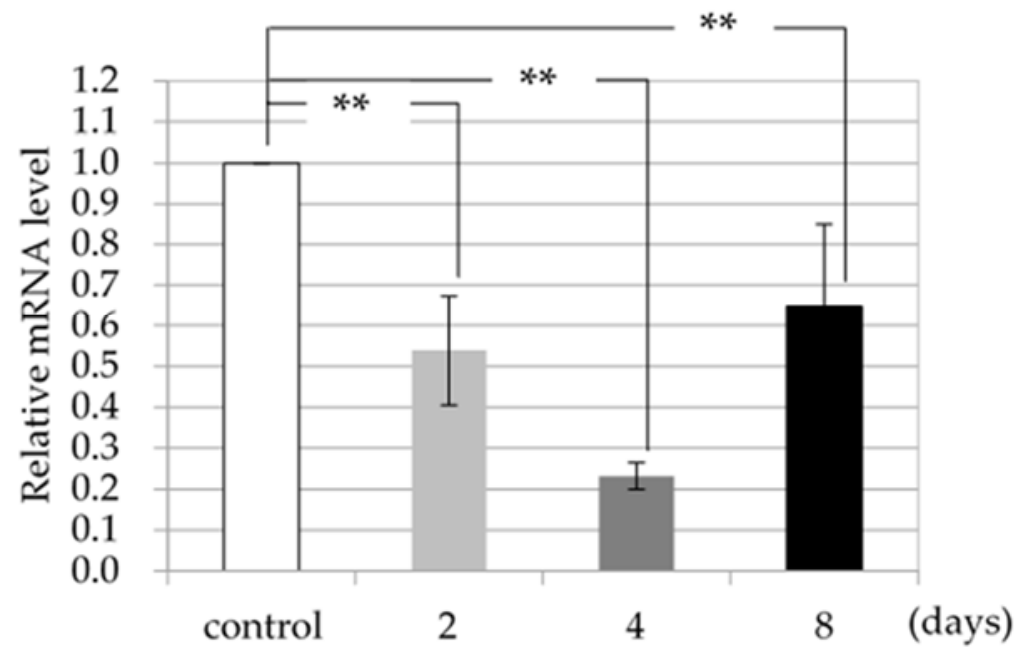

Figure 4. Effect of ISLCs on the gene expression level of IL6 in 3T3-L1 cells 2, 4, and 8 days after differentiation. The IL6 expression level of cultured cells treated with $1.0 \mathrm{mg} / \mathrm{mL}$ ISLCs and untreated control cells 2, 4, and 8 days after differentiation was measured by real-time PCR. The cells were cultured 
in medium containing $1.0 \mathrm{mg} / \mathrm{mL}$ ISLCs. The cells in the medium without ISLCs were used as a control. Gene expression was expressed relative to untreated control cells (1.0). The mRNA levels of the target genes were normalized to the values of GAPDH. Values are expressed as the mean $\pm \mathrm{SD}$; ** $p<0.01$, compared to control cells.

\section{Discussion}

In this study, we investigated the effects of ISLCs on lipid accumulation in 3T3$\mathrm{L} 1$ adipocytes. The results reveal that the addition of $1.0 \mathrm{mg} / \mathrm{mL}$ ISLCs to the culture medium was associated with significantly less lipid accumulation compared to untreated controls; thus, ISLCs may contain components that inhibit lipid accumulation in adipocytes (Figure 1). Furthermore, the GDPH activity in fully differentiated cells was decreased compared to that in treated cells (Figure 2). GPDH is known to be an enzyme involved in adipogenesis in fat cells. In this study, the GPDH activity was decreased in ISLCtreated cells, which suggests that ISLCs might have an inhibitory effect on lipogenesis in adipocytes.

IL6 has multiple effects on adipose tissue. Chronically high levels of IL6 may alter gene or protein expression, thus influencing basal lipolysis [14]. Moreover, high local concentrations of IL6 can modulate leptin production and lipid metabolism in human adipose tissue $[15,16]$. IL6 may also directly influence human adipocyte metabolism by decreasing LPL activity, according to studies on the 3T3-L1 adipocyte model system [17,18].

In this study, the IL6 expression of 3T3-L1 cells was decreased and the adipocyte LPL activity was increased following ISLCs treatment compared with untreated controls (Figures 3 and 4). Thus, ISLC-related factors might suppress IL6 expression and indirectly affect LPL activity. IL6 is thought to be a paracrine modulator of adipose tissue in obese human beings because LPL activity is inhibited by an increase in leptin production [19]. Although this study did not assess leptin levels, we postulate that the decreased IL6 expression was associated with reduced leptin levels, thereby increasing LPL activity.

In conclusion, ISLCs were associated with reduced lipid accumulation in adipocytes, with effects on GPDH activity, IL6 expression, and LPL activity, as observed throughout the differentiation period. IL6 is believed to decrease LPL activity and control adipocyte size in humans; however, it is unclear how ISLCs and which specific ISLC components affect IL6 expression. We fractionated the ISLCs extracted at various temperatures into functional components and found that only the ISLCs extracted at $100{ }^{\circ} \mathrm{C}$ showed a significant difference. We found insoluble fractions with a molecular weight under 10,000 that were thought to be involved in lipid accumulation in adipocytes. However, the functional components have not yet been concretely determined. In this study, we could not clarify the detailed relationship between IL6 expression and the suppression of lipid accumulation in cells treated with ISLCs. Therefore, future research should be undertaken to elucidate this mechanism and detail the functional components in ISLCs.

Author Contributions: All authors contributed to writing and editing this paper (Y.M., T.I. (Takeshi Imai), T.E., T.I. (Takafumi Iguchi) and M.T.). All authors have read and agreed to the published version of the manuscript.

Funding: This research was supported in part by Kobe College and Kobe College Megumi Association. Institutional Review Board Statement: Not applicable.

Informed Consent Statement: Not applicable.

Conflicts of Interest: The authors declare no conflict of interest.

\section{References}

1. Ministry of Health, Labor and Welfare. Available online: https://www.mhlw.go.jp/toukei/saikin/hw/life/life19/dl/life19-15 .pdf (accessed on 6 June 2021).

2. Ministry of Agriculture, Forestry and Fisheries. Available online: http://www.maff.go.jp/j/wpaper/w_maff/h26/h26_h/trend/ part1/chap1/c1_3_01.html (accessed on 20 May 2021). 
3. Ministry of Agriculture, Forestry and Fisheries. Available online: https:/ / www.e-stat.go.jp/stat-search/files?page=1\&layout= datalist \&toukei $=00500300 \&$ tstat $=000001017950 \&$ cycle $=8 \&$ year $=20191 \&$ month $=0 \&$ tclass $1=000001032890 \&$ tclass $2=00000115138$ 7 (accessed on 20 May 2021).

4. Rodgers, R.J.; Tschöp, M.H.; Wilding, J.P. Anti-obesity drugs: Past, present and future. Dis. Models Mech. 2012, 5, 621-626. [CrossRef] [PubMed]

5. Barengolts, E.; Smith, E.D.; Reutrakul, S.; Tonucci, L.; Anothaisintawee, T. The Effect of Probiotic Yogurt on Glycemic Control in Type 2 Diabetes or Obesity: A Meta-Analysis of Nine Randomized Controlled Trials. Nutrients 2019, 11, 671. [CrossRef] [PubMed]

6. González, S.; Fernández-Navarro, T.; Arboleya, S.; de Los Reyes-Gavilán, C.G.; Salazar, N.; Gueimonde, M. Fermented Dairy Foods: Impact on Intestinal Microbiota and Health-Linked Biomarkers. Front. Microbiol. 2019, 10, 1046. [CrossRef] [PubMed]

7. Saito, Y.; Wanezaki, K.; Kawato, A.; Imayasu, S. Structure and activity of angiotensin I converting enzyme inhibitory peptides from sake and sake lees. Biosci. Biotechnol. Biochem. 1994, 58, 1767-1771. [CrossRef] [PubMed]

8. Izu, H.; Shibata, S.; Fujii, T.; Matsubara, K. Sake cake (sake-kasu) ingestion increases branched-chain amino acids in the plasma, muscles, and brains of senescence-accelerated mice prone 8. Biosci. Biotechnol. Biochem. 2019, 83, 1490-1497. [CrossRef] [PubMed]

9. Kubo, H.; Hoshi, M.; Matsumoto, T.; Irie, M.; Oura, S.; Tsutsumi, H.; Hata, Y.; Yamamoto, Y.; Saito, K. Sake lees extract improves hepatic lipid accumulation in high fat diet-fed mice. Lipids Health Dis. 2017, 16, 106. [CrossRef] [PubMed]

10. Kawakami, K.; Moritani, C.; Uraji, M.; Fujita, A.; Kawakami, K.; Hatanaka, T.; Suzaki, E.; Tsuboi, S. Sake lees hydrolysate protects against acetaminophen-induced hepatotoxicity via activation of the Nrf2 antioxidant pathway. J. Clin. Biochem. Nutr. 2017, 61, 203-209. [CrossRef] [PubMed]

11. Vicennati, V.; Vottero, A.; Friedman, C.; Papanicolaou, D.A. Hormonal regulation of interleukin-6 production in human adipocyte. Int. J. Obes. 2002, 26, 905-911. [CrossRef] [PubMed]

12. Roytblat, L.; Rachinsky, M.; Fisher, A.; Greemberg, L.; Shapira, Y.; Douvdevani, A.; Gelman, S. Raised Interleukin-6 Levels in Obese Patients. Obes. Res. 2000, 8, 673-675. [CrossRef]

13. Kern, P.A.; Ranganathan, S.; Li, C.; Wood, L.; Ranganathan, G. Adipose tissue tumor necrosis factor and interleukin-6 expression in human obesity and insulin resistance. Am. J. Physiol. Endocrinol. Metab. 2001, 280, 745-751. [CrossRef]

14. Rotter, V.; Nagaev, I.; Smith, U. Interleukin-6(IL-6)Induces Insulin Resistance in 3T3-L1 Adipocytes and Is, Like IL-8 and Tumor Necrosis Factor-,Overexpressed in Human Fat Cells from Insulin-resistant Subjects. J. Biol. Chem. 2003, 278, 45777-45784. [CrossRef] [PubMed]

15. Granowitz, E.V. Transforming Growth Factor- $\beta$ Enhances and Pro-inflammatory Cytokines Inhibit OB Gene Expression in 3T3-L1 Adipocytes. Biochem. Biophys. Res. Commun. 1997, 240, 382-385. [CrossRef] [PubMed]

16. Bruun, J.M.; Pedersen, S.B.; Kristensen, K.; Richelsen, B. Effects of pro-inflammatory cytokines and chemokines on leptin production in human adipose tissue in vitro. Mol. Cell. Endocrinol. 2002, 190, 91-99. [CrossRef]

17. Trujillo, M.E.; Sullivan, S.; Harten, I.; Schneider, S.H.; Greenberg, A.S.; Fried, S.K. Interleukin-6 Regulates Human Adipose Tissue Lipid Metabolism and Leptin Production in Vitro. J. Clin. Endocrinol. Metab. 2004, 89, 5577-5582. [CrossRef] [PubMed]

18. Greenberg, A.S.; Nordan, R.P.; McIntosh, J.; Calvo, J.C.; Scow, R.O.; Jablons, D. Interleukin 6 Reduces Lipoprotein Lipase Activity in Adipose Tissue of Mice in Vivo and in 3T3-L1 Adipocytes: A Possible Role for Interleukin 6 in Cancer Cachexia. Cancer Res. 1992, 52, 4113-4116. [PubMed]

19. Fried, S.K.; Bunkin, D.A.; Greenberg, A.S. Omental and Subcutaneous Adipose Tissues of Obese Subjects Release Interleukin-6: Depot Difference and Regulation by Glucocorticoid. J. Clin. Endocrinol. Metab. 1998, 83, 847-850. [CrossRef] [PubMed] 